\title{
Perbandingan Efektifitas Pemberian Kompres Madu dan Kompres Gula Kristal terhadap Penyembuhan Luka pada Tikus Putih
}

\author{
Winanda Rizki Bagus Santosa ${ }^{1}$, Riyono ${ }^{1}$ \\ ${ }^{1}$ Institut Ilmu Kesehatan Bhakti Wiyata Kediri \\ Email : winandarizky@gmail.com
}

Received 18 April 2018; Accepted 8 May 2018; Published 15 May 2018

\begin{abstract}
Honey and crystals sugar was complementary materials for wound care in a modern era. In other easy to get it, the curative characteristic in the honey and crystal sugar, it can to cure of the injury soon. The injury can easy to heal so the cost is cheap. This research aims to determine comparation of the effect of honey compress and crystals sugar compress on the process of wound healing in mice. This type of research is a True Experiment Randomized Design with research design Post Test Only Control Group Design conducted on 15 white rats received artificial injury. The sample selected by RCT (Randomized Control Trial) it divided into three groups, namely honey compress treatment group $(\mathrm{n}=5)$, crystal sugar compress the treated group $(n=5)$, and the control group $(n=5)$. Independent variables that influence honey compress and the crystals sugar compress, while the dependent variable healed wound (edema, hyperemia, pus, granulation) on the observation every day for seven days. The data obtained, than it analyzed using Kolmogorov-Smirnov test by level of significance $p<0.05$. The results showed the influence statistic significantly granting of honey compress and sugar crystals compress third day of observation. Kolmogorov-Smirnov test (edema $p=0.013$, hyperemia $\mathrm{p}=0.013$, pus $\mathrm{p}=0.013$, and granulation $\mathrm{p}=0.013$ ). Compresses can be summed giving honey and crystals sugar compress significantly effect the process of wound healing. Based on these results, it suggested in other that use a pack of honey or crystals sugar compress can be applied as comprehensive wound care.
\end{abstract}

Keywords : Cystals sugar compress, honey compress, wound.

Copyright $\odot 2018$ STIKes Surya Mitra Husada

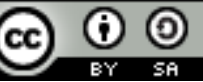

This is an open-acces article distributed under the terms of the Creative Commons Attribution-ShareAlike 4.0 International License. 


\section{PENDAHULUAN}

Manusia selalu aktif dalam beraktivitas dan dapat menyebabkan luka. Luka adalah suatu kerusakan kontinuitas jaringan tubuh yang dapat menyebabkan terganggunya fungsi tubuh sehingga dapat mengganggu aktivitas sehari-hari (Hidayat, 2006). Perawatan luka adalah suatu tindakan untuk membantu menciptakan kondisi luka yang baik pada daerah luka untuk penyembuhan dengan mengeluarkan debris, seperti benda asing dan jaringan lunak yang mengalami defitalisasi yang apabila terus menerus dibiarkan akan mengakibatkan terjadinya infeksi (Morison, 2004). Proses penyembuhan luka dapat terjadi secara spontan tanpa pengobatan, ada juga beberapa bahan perawatan yang dapat membantu mendukung proses penyembuhan jaringan (Potter, 2005).

Di Indonesia, tindakan terhadap perawatan luka masih sangat kurang. Padahal luka adalah permasalahan sederhana yang bisa menjadi kompleks jika tidak segera disembuhkan. Di Amerika, untuk perawatan luka saja, dinas kesehatan nasional Amerika menganggarkan dana tidak kurang dari 174 miliyar dollar pertahunnya (Biswas, 2010). Sebuah jumlah yang cukup besar, semakin lama proses penyembuhan luka semakin banyak biaya yang dikeluarkan untuk perawatan luka. Untuk itu penting dilakukan penelitian perawatan luka yang kiranya tidak memerlukan biaya banyak yaitu dengan menggunakan bahan-bahan yang mudah didapat seperti madu dan gula kristal.

Madu sejak dahulu sering dipakai untuk menyembuhakan berbagai macam penyakit, tepatnya sejak jaman mesir kuno pada tahun 2000 SM. Hal ini, dikarenakan madu mempunyai sifat anti bakteri yang dapat membantu mengatasi infeksi luka. Sifat anti inflamasi pada madu dapat mengurangi nyeri serta meningkatkan sirkulasi yang berpengaruh pada proses penyembuhan luka (Farrokhi, 2011). Pengunaan madu untuk perawatan luka sudah sering dilakukan, bahkan kedokteran modern telah membuktikan kalau madu merupakan obat penyembuh luka yang unggul (Suranto, 2007). Madu sangat efektif menyembuhkan luka karena madu kaya akan nutrisi dimana nutrisi itu sangat dibutuhkan untuk penyembuhan luka. Madu memiliki osmolitas tinggi yang mampu menyerap air dan memperbaiki sirkulasi dan pertukaran udara di area luka (Suranto, 2007).

Ada bahan lain yang dimanfaatkan untuk perawatan luka yaitu gula kristal. Gula kristal dimanfaatkan untuk perawatan luka karena diketahui gula juga mempunyai sifat anti bakteri, dapat mengontrol aktivitas cairan, menstimulasi makrofag untuk melakukan pembersihan luka, menghilangkan edema, dan mengurangi infeksi lokal pada luka. Gula kristal dipromosikan untuk perawatan luka sekitar tahun $1714 \mathrm{M}$ oleh Zoinin dan sekarang penggunaan gula sebagai penyembuhan luka telah banyak digunakan di Negara-negara maju seperti Amerika Latin, Eropa dan Asia (Biwas, 2010).

\section{METODE PENELITIAN}

Penelitian ini menggunakan metode true eksperiment randomized post test only control group. Sampel pada penelitian ini digunakan hewan coba tikus putih dengan kriteria umur 3 bulan, jenis kelamnin jantan, berat badan antara 50-100 gram, dan tidak cacat. Sampel dibagi dalam tiga kelompok, yaitu satu kelompok kontrol (tanpa diberi perlakuan), dan dua kelompok perlakuan (satu kelompok perlakuan kompres madu dan satu kelompok perlakuan kompres gula kristal). Pembagian kelompok dilakukan secara RCT (Randomized Control Trial). Berdasarkan rumus Roscoe didapatkan jumlah sampel sebanyak 15 ekor tikus putih yamg terbagi dalam tiga kelompok dengan masing-masing kelompok 5 ekor tikus putih. Penelitian ini dilakukan di Institut Ilmu Kesehatan Bhakti Wiyata Kediri pada tanggal 15 - 23 Februari 2018.

Variabel independen dalam penelitian ini adalah kompres madu dan kompres gula kristal. Perawatan luka dengan kompres madu diberikan dua kali per hari, dosis pemberian $0.3 \mathrm{ml}$ dan mulai diberikan 24 jam pasca perlukaan. Sedangkan perawatan luka dengan kompres gula kristal 3 gram, perawatan juga diberikan dua kali per hari dengan pemberian 
dilakukan setelah luka 24 jam pasca perlukaan. Variabel dependen yaitu penyembuhan luka dengan kriteria tidak ada edema, tidak ada pus, terjadi hiperemi, dan munculnya granulasi.

Alat dan bahan yang digunakan dalam penelitian ini yaitu : 1) alat dan bahan insisi : Pisau cukur, Pisau bedah, Scapel, Penggaris, Alkohol 70\%, Obat anestesi (lidocain), Spuit 1 cc, Kapas dan kasa, Sarung tangan, Perlak, Jas laboratorium; 2) alat dan bahan perawatan : Set perawatan luka, Sarung tangan, Madu murni (madu bunga randu), Gula kristal (gulaku), Kasa, Plester, Bengkok, Kom, Tempat sampah.

Instrumen pengumpulan data menggunakan lembar observasi untuk mengukur proses penyembuhan luka. Observasi dilakukan setiap hari selama tujuh hari. Data yang diperoleh di tabulasi dan dianalisis menggunakan uji statistik Kolmogorov-Smirnov dengan tingkat kemaknaan $a \leq 0,05$.

\section{HASIL PENELITIAN}

Percobaan dilakukan terhadap 15 ekor tikus putih. Dari 15 ekor tikus putih tersebut terbagi dalam tiga kelompok yaitu kelompok I adalah kelompok perawatan dengan kompres gula kristal, kelompok II adalah kelompok perawatan dengan kompres madu, dan kelompok III merupakan kelompok kontrol dan tidak dilakukan perawatan. Kondisi luka diobservasi satu hari setelah hari perawatan pertama yaitu mulai tanggal 17 Februari 2018, dimana kondisi luka diobservasi dari aspek nilai hiperemi, edema, granulasi, dan pus.

Tabel 1 nilai edema observasi hari ke-3

\begin{tabular}{lcccc}
\hline & \multicolumn{4}{c}{ Nilai Edema } \\
\hline Madu & Tidak ada & sedikit & sedang & banyak \\
Gula & 5 & 0 & 0 & 0 \\
Kontrol & 5 & 0 & 0 & 0 \\
& 0 & 1 & 3 & 1 \\
\hline
\end{tabular}

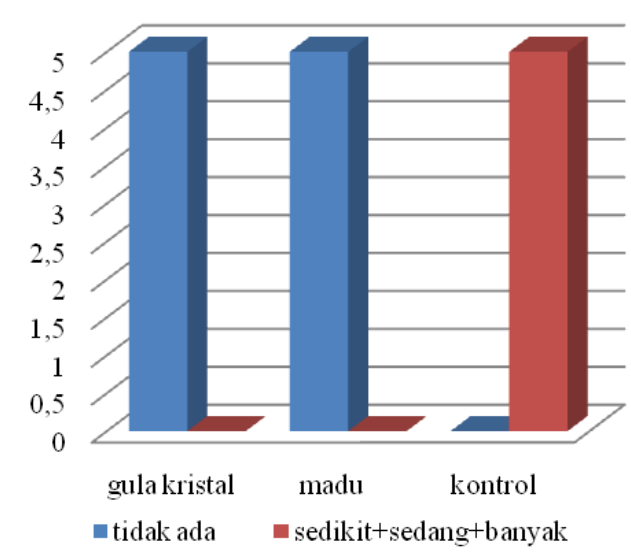

Gambar 1 nilai edema observasi hari ke-3 
Tabel 2 nilai hiperemi observasi hari ke-3

\begin{tabular}{lcccc}
\hline & \multicolumn{4}{c}{ Nilai Hiperemi } \\
\hline Madu & 0 & sedikit & sedang & banyak \\
Gula & 0 & 1 & 4 & 0 \\
Kontrol & 5 & 2 & 3 & 0 \\
\hline
\end{tabular}

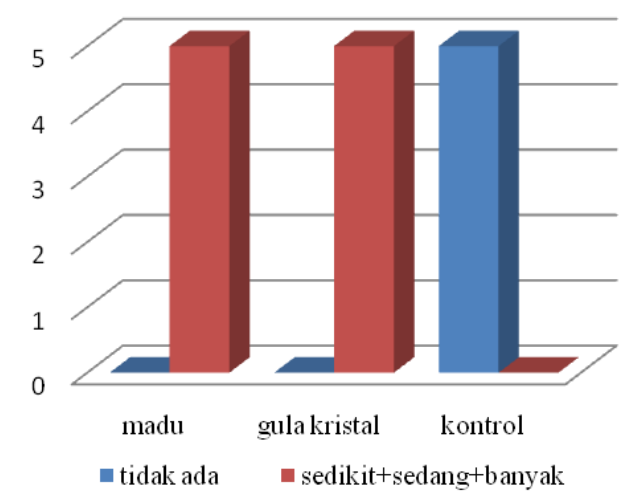

Gambar 2 nilai hiperemi observasi hari ke-3

Tabel 3 nilai pus observasi hari ke-3

\begin{tabular}{lcccc}
\hline & \multicolumn{5}{c}{ Nilai Pus } & sedang & banyak \\
\hline Madu & 5 & sedikit & 0 & 0 \\
Gula & 5 & 0 & 0 & 0 \\
Kontrol & 0 & 0 & 2 & 1 \\
\hline
\end{tabular}

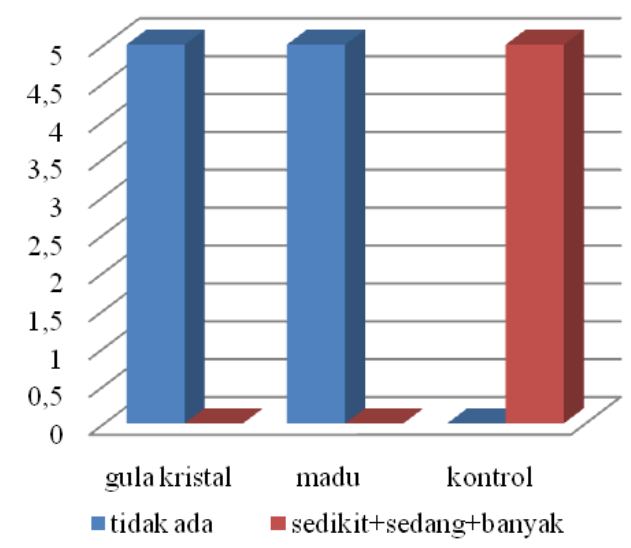

Gambar 2 nilai hiperemi observasi hari ke-3 
Tabel 4 nilai granulasi observasi hari ke-3

\begin{tabular}{lcccc}
\hline & \multicolumn{4}{c}{ Nilai Granulasi } \\
\hline Madu & Tidak ada & sedikit & sedang & banyak \\
Gula & 0 & 5 & 0 & 0 \\
Kontrol & 0 & 5 & 0 & 0 \\
& 5 & 0 & 0 & 0 \\
\hline
\end{tabular}

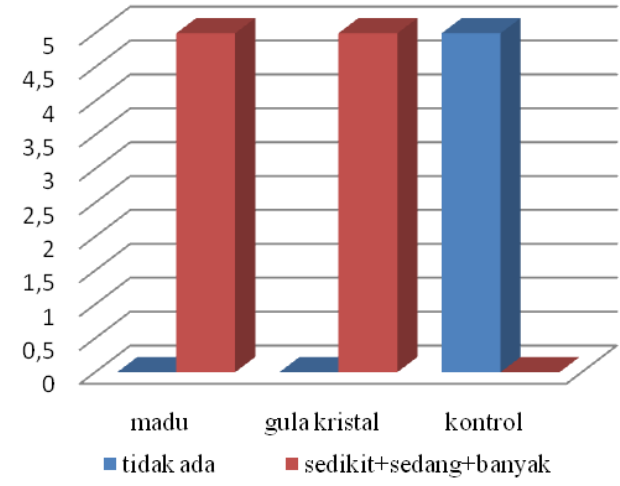

Gambar 2 nilai hiperemi observasi hari ke-3

Dari hasil perbandingan observasi hari ke-3 kelompok madu dengan kontrol diketahui bahwa tidak terdapat perbedaan nilai edema, nilai hiperemi, nilai pus, dan nilai granulasi antara kelompok perlakuan kompres gula dengan kompres madu. Dan hasil uji statistik Kolmogorov-Smirnov didapatkan nilai $\mathrm{p}=1,000$ untuk nilai edema, $\mathrm{p}=1,000$ untuk nilai hiperemi, $\mathrm{p}=1,000$ untuk nilai pus, dan $\mathrm{p}=1,000$ untuk nilai granulasi.

Sedangkan hasil perbandingan observasi hari ke-3 kelompok gula dengan kontrol diketahui bahwa terdapat perbedaan nilai edema, nilai hiperemi, nilai pus, dan nilai granulasi antara kelompok perlakuan kompres gula dengan kontrol. Dan hasil uji statistik KolmogorovSmirnov didapatkan nilai $\mathrm{p}=0,013$ untuk nilai edema, $\mathrm{p}=0,013$ untuk nilai hiperemi, $\mathrm{p}=0,013$ untuk nilai pus, dan $\mathrm{p}=0,013$ untuk nilai granulasi.

Dan untuk perbandingan observasi hari ke-3 kelompok madu dengan kontrol diketahui bahwa juga terdapat perbedaan nilai edema, nilai hiperemi, nilai pus, dan nilai granulasi antara kelompok perlakuan kompres madu dengan kontrol. Dan hasil uji statistik Kolmogorov-Smirnov didapatkan nilai $\mathrm{p}=0,013$ untuk nilai edema, $\mathrm{p}=0,013$ untuk nilai hiperemi, $\mathrm{p}=0,013$ untuk nilai pus, dan $\mathrm{p}=0,013$ untuk nilai granulasi.

\section{PEMBAHASAN}

Berdasarkan hasil penelitian pengaruh pemberian kompres madu dan kompres gula kristal terhadap penyembuhan luka pada tikus putih di Laboratorium Anatomi Institut Ilmu Kesehatan Bhakti Wiyata Kediri, menunjukan bahwa terdapat perbedaan yang bermakna secara statistik pada hari observasi ke-3 antara perawatan luka dengan kompres madu dan kompres gula kristal dibanding dengan kelompok kontrol. Dengan uji statistik KolmogorovSmirnov menunjukan, perbandingan antara kompres madu dan gula kristal dibanding kelompok kontrol pada hari observasi ke-3 nilai edema $\mathrm{p}=0,013$, hiperemi $\mathrm{p}=0,013$, pus $\mathrm{p}=0,013$ dan granulasi $\mathrm{p}=0,013$. Tetapi, antara kelompok kompres madu dengan kompres gula kristal tidak terdapat perbedaan yang bermakna secara statistik. Hasil uji KolmogorovSmirnov didapatkan nilai edema $\mathrm{p}=1,000$, hiperemi $\mathrm{p}=1,000$, pus $\mathrm{p}=1,000$, dan granulasi $\mathrm{p}=1,000$. 
Penyembuhan luka merupakan proses fisiololgis kualitas dari kehidupan jaringan yang berhubungan dengan regenerasi jaringan. Kemampuan sel dan jaringan melakukan regenerasi atau kembali ke struktur normal mempengaruhi penyembuhan luka. Fase penyembuhan luka terdiri dari tiga fase yaitu fase inflamasi, fase proliferasi, dan fase maturasi. Fase inflamasi merupakan reaksi tubuh terhadap luka yang dimulai setelah beberapa menit dan berlangsung selama sekitar tiga hari setelah cedera (Potter, 2005). Dalam fase ini pengamatan secara makroskopis dilakukan untuk menilai aspek edema dan cairan pus pada luka.

Observasi hari ke-3 kelompok kompres madu dan kompres gula kristal sudah tidak ada edema, sedangkan kelompok kontrol masih terjadi edema. Terdapat perbedaan yang bermakna kompres madu dan kompres gula kristal dibandingkan kontrol. Hal ini diduga disebabkan madu mengandung protein atau asam amino yang mampu memperbaiki tekanan osmotik plasma dan sifat anti inflamasinya dapat mencegah infeksi serta meningkatan sirkulasi yang berpengaruh pada proses penyembuhan luka (Zakaria, 2009). Cara kerja anti inflamasi madu diduga melalui modulasi respon inflamasi dan mengendalikan angiogenesis (Farrokhi, 2011). Dan asam amino dalam madu diduga berguna untuk pertumbuhan sintesa bahan lain dan sumber energi misalnya untuk sintesa kolagen. Madu diduga pula mempunyai aktivitas fagositosis dan meningkatkan pembelahan sel limfosit, serta merangsang produksi TNF-alfa di makrofag yang dapat meningkatkan daya tahan tubuh terhadap infeksi (Farrokhi, 2011). Begitu juga dengan gula kristal, yang mempunyai sifat anti bakteri yang mengurangi resiko terjadinya infeksi. Selain itu, sifat osmolaritas yang tinggi pada gula menghilangkan edema sehingga mempercepat penyembuhan luka (Biwas, 2010).

Adanya cairan pus pada luka merupakan indikasi infeksi. Pertahanan tubuh yang bekerja utamanya ialah netrofil, yang mulai memakan bakteri dan debris yang kecil. Netrofil akan mati dalam beberapa hari dan meninggalkan eksudat. Pada inflamasi kronik, netrofil yang mati membentuk pus (Potter, 2005). Hasil penelitian terhadap 5 ekor tikus putih yang diberi perlakuan kompres madu maupun kompres gula kristal tidak ada pus pada hari observasi ke-3. Hal ini dikarenakan sifat anti bakteri dari madu dan gula kristal yang mampu mencegah terjandinya infeksi sehingga tidak ada pus.

Sifat anti bakteri ini disebabkan madu memiliki osmolaritas tinggi yang mampu menyerap air. Madu terdiri 84\% gula dan kadar air 15-20\% dengan sedikitnya kandungan air akan membuat bakteri tidak dapat hidup, karena tidak ada bakteri yang mampu hidup pada kadar air kurang dari 17\% (Suranto, 2007). Selain itu, madu juga mengandung senyawa hidrogen peroksida. Senyawa ini diketahui bersifat membunuh bakteri meskipun konsentrasi hidrogen peroksida yang terdapat dalam madu lebih kecil larutan hidrogen peroksida $3 \%$ yang biasa dipakai sebagai antiseptik (Olaitan dkk, 2007). Begitu juga dengan gula kristal, pus yang tidak terdapat pada luka yang diberi kompres gula krital karena gula juga mempunyai sifat anti bakteri. Efek osmolaritas gula mampu menurunkan PH luka sehingga meningkatkan efek bakteriostatik dan menghambat pertumbuhan bakteri dan dengan menurunnya kadar air di daerah luka bakteri tidak dapat tumbuh sehingga tidak terdapat pus (Biwas, 2010).

Hasil penelitian observasi pada hari ke-3 hiperemi terjadi pada luka kelompok perlakuan kompres madu dan gula kristal. Hiperemi menunjukkan bahwa sirkulasi darah perifer lancar. Pada kelompok madu lebih cepat terjadi hiperemi dibanding kontrol. Hal ini disebabkan madu mempunyai sifat osmolaritas yang mampu menyerap air dan membuat suasana luka menjadi lembab, hal ini menyebabkan berbagai sel dari jaringan yang terluka akan mendapat suplai nutrisi yang dibutuhkan luka secara adekuat untuk metabolisme jaringan. Hasil penelitian menunjukan bahwa lingkungan lembab pada luka lebih baik daripada lingkungan kering (Zakaria dkk, 2009). Begitu juga pada kelompok kompres gula kristal, sifat osmolaritas yang tinggi pada gula kristal mampu menyerap air. Selain itu, aktivitas gula juga dipengarruhi oleh air sehingga gula mampu menciptakan kondisi kelembaban yang seimbang pada luka (Biwas, 2010).

Setelah hiperemi fase selanjutnya yaitu fase proliferasi, fase ini terjadi dalam waktu 3-24 hari. Aktivitas utama fase proliferasi adalah mengisi luka dengan jaringan penyambung 
atau jaringan granulasi baru dan menutup bagian atas luka dengan epitelisasi. Dalam fase ini fibroblas mempunyai peranan mensintesis kolagen yang akan menutup luka. Untuk menjalankan peranannya dengan baik fibroblas memerlukan vitamin $\mathrm{B}$ dan $\mathrm{C}$, oksigen, dan asam amino. Hasil penelitian pada hari observasi ke-3 dan ke-4 granulasi sudah terjadi pada kelompok perlakuan kompres madu dan kompres gula kristal, sedangkan kelompok kontrol belum.

Madu mengandung vitamin A, B, C, B kompleks dan mineral Zinc (Olaitan dkk, 2007). Vitamin B dan C dalam madu diduga membantu fibroblas dalam mensintesis kolagen. Selain itu, madu juga mengandung asam amino dimana senyawa ini diduga mempunyai peranan dalam pembentukan kolagen. Sedangkan mineral Zinc yang terdapat di madu diduga mempunyai peranan penting dalam sintesis protein dan proses replikasi sel-sel tubuh serta berperan khusus dalam metabolisme kulit dan jaringan ikat (Zakaria, 2009). Begitu pula dengan gula kristal, mempunyai kemampuan untuk menjaga kesimbangan cairan pada luka sehingga proses oksigenasi berjalan lancar dan luka yang cepat mengalami granulasi. Sesuai teori sebelumnya penyembuhan luka dari fase inflamasi sampai proliferasi dibutuhkan waktu 1-24 hari, disini penggunaan kompres madu dan kompres gula kristal berlangsung lebih cepat dibandingkan dengan proses penyembuhan luka secara normal.

\section{KESIMPULAAN DAN SARAN}

\section{Kesimpulan}

Dari hasil penelitian tentang perbandingan efektifitas kompres madu dan kompres gula kristal terhadap penyembuhan luka pada tikus putih diketahui terdapat perbedaan yang bermakna secara statistik pada hari observasi ke-3 antara kelompok kompres madu dan kompres gula kristal dibanding kontrol. Dan tidak terdapat perbedaan yang bermakna secara statistik antara kompres madu dan kompres gula kristal pada hari observasi ke-3.

\section{Saran}

Peneliti menyarankan: 1) Dilakukannya perawatan luka dengan kompres madu dan kompres gula pada manusia, 2) Perlu dilakukan penelitian lanjutan tentang efek madu dan gula pada luka yang diamati secara mikrokopis, 3) Perlu adanya standarisasi jenis serta komposisi madu dan gula kristal dalam penggunaan di bidang medis.

\section{KEPUSTAKAAN}

Atanu, B., dkk. (2010). Use of Sugar on the Healing of Diabetic Ulcers : A Review. Journal of Diabetes Science and Technology, Vol. 4, Hal. 1139-1145.

Farrokhi, Majid, Reza, dkk. (2011). Effect of Honey on Peridural Fibrosis formation after Laminectomy in Rats : A Novel Experimental Study. Evidence-Based Complementari and Alternatif Medicine.

Hidayat, A., \& Aziz. (2006). Pengantar Kebuhan Dasar Manusia Aplikasi dan Konsep Dan Proses Keperawatan. Jakarta : Salemba Medika. Hal. 133-136.

Morison, \& Moya, (2004). Manajemen luka. Jakarta : EGC. Hal. 1-4.

Olaitan, Peter, B., dkk. (2007). Honey : A Reservoir For Microorganism and An Inhibitory Agent For Microbes. African Health Science, Vol. 7, No. 3, Hal. 159-165. 
Potter, Patricia, A., \& Perry, A.G. (2005). Buku Ajar Fundamental Keperawatan Konsep, Proses, dan Praktik, Ed. 4 Vol. 2. Jakarta : EGC. Hal. 1852-1864.

Suranto, A. (2007). Terafi Madu. Jakarta : Penebar Swadaya. Hal. 26-46.

Zakaria, M., dkk. (2009). Efektifitas Perawatan Luka Incisi Dengan Madu dan Povidone Iodine 10\%. Ners journal jurnal ners, Vol. 4 No. 1, Hal. 1-8. 